\title{
REVIEW
}

\section{Clinical application of cVEMPs and oVEMPs in patients affected by Ménière's disease, vestibular neuritis and benign paroxysmal positional vertigo: a systematic review}

\author{
Applicazione clinica dei cVEMPs ed oVEMPs nei pazienti affetti da malattia di Ménière, \\ neurite vestibolare e vertigine parossistica posizionale benigna: \\ una revisione sistematica
}

\author{
A. SCARPA ${ }^{1}$, F.M. GIOACCHINI ${ }^{2}$, E. CASSANDRO ${ }^{1}$, M. TULLI ${ }^{3}$, M. RALLI ${ }^{4}, M^{2} \cdot$ RE$^{2}$, C. CASSANDRO ${ }^{5}$ \\ ${ }^{1}$ Department of Medicine and Surgery, University of Salerno, Italy; ${ }^{2}$ ENT Unit, Department of Clinical and Molecular \\ Sciences, Polytechnic University of Marche, Ancona, Italy; ${ }^{3}$ Department of Otorhinolaryngology, San Raffaele \\ Scientific Institute, Milan, Italy; ${ }^{4}$ Department of Sense Organs, Sapienza University of Rome, Italy; ${ }^{5}$ Surgical \\ Sciences Department, University of Turin, Italy
}

\section{SUMMARY}

Vestibular evoked myogenic potentials (VEMPs) are increasingly used for different pathologies with new clinical insights. Although the study of otolithic function selectively in both its saccular (cervical VEMPs) and utricular (ocular VEMPs) parts does not represent a recent achievement, the clinical utility of this tool is still emerging. The aim of the present report is to define advances in application of VEMPs in diagnosis and clinical study of vestibular neuritis, Ménière's disease and benign paroxysmal positional vertigo. To perform a systematic review of the literature, three appropriate strings were run in PubMed to retrieve dedicated articles. A double cross-check was performed on citations and two independent investigators independently reviewed all full-text articles and performed a comprehensive quality assessment. Of 140 articles identified, 26 articles were included, comprising a total of 1,181 patients affected by vestibular neuritis (296 subjects), Ménière's disease (378 patients) and benign paroxysmal positional vertigo (507 patients). Overall, the use of both cVEMP and oVEMP appeared particularly useful in improving the topographic diagnosis of vestibular neuritis. Most $(\mathrm{n}=8)$ of the studies dedicated to Ménière's disease and benign paroxysmal positional vertigo (10 overall) also reported significantly abnormal VEMP values compared to healthy controls. Although further reports will be necessary to better define normal threshold levels of VEMPs for each pathology, our review suggests that VEMPs may represent a useful aid in improving the diagnostic accuracy for these three common vestibular pathologies.

KEY WORDS: VEMPs • Ménière's disease • Vestibular neuritis • BPPV • Peripheral vertigo

\section{RIASSUNTO}

Attualmente l'applicazione dei potenziali evocati vestibolari miogenici (VEMPs) sta crescendo in molte e differenti patologie. La possibilità di studiare la funzione vestibolare in modo selettivo sia nel sacculo (VEMPs cervicali) sia nell'utricolo (VEMPs oculari) rappresenta una possibilità recentemente acquisita e l'utilità di tali indagini strumentali sta ancora emergendo e sempre meglio delineandosi. Lo scopo della nostra revisione è stato quello di definire per quanto possibile le novità nell'applicazione dei VEMPs per la diagnosi e l'approfondimento clinico di tre importanti entità patologiche: la neurite vestibolare, la malattia di Ménière e la vertigine posizionale benigna. Per realizzare questa revisione sistematica abbiamo quindi utilizzato tre differenti stringhe di parole chiave su PubMed ricercando in tal modo tutti gli articoli attinenti a queste tematiche. Una doppia verifica incrociata è stata eseguita da due degli autori prima su tutti i titoli scaturiti dalla ricerca e poi sugli specifici testi degli articoli selezionati al fine di poterne accertarne la qualità e la effettiva pertinenza. Su un totale di 140 articoli identificati, 26 studi sono stati inclusi nella revisione. Questi studi comprendevano 1.181 pazienti affetti rispettivamente da neurite vestibolare (296 soggetti), malattia di Ménière (378 soggetti) e vertigine parossistica benigna (507 soggetti). Per quanto concerne la neurite vestibolare complessivamente l'utilizzo dei cVEMPs e degli oVEMPs è apparso particolarmente utile nel migliorare l'accuratezza della diagnosi topografica della malattia. Sia per la malattia di Ménière che per la vertigine parossistica posizionale benigna ben 8 studi su 10 che comprendevano anche un gruppo controllo di pazienti sani hanno mostrato come la registrazione dei VEMPs sia risultata significativamente anormale nei soggetti patologici rispetto a quelli sani. Sebbene ulteriori studi saranno certamente necessari per meglio definire le soglie di normalità nei valori dei VEMPs per ogni singola entità patologica qui analizzata, al momento possiamo concludere che la nostra revisione indica la reale utilità della registrazione dei VEMPs. Infatti se integrata alle altre opzioni strumentali disponibili essa sembra realmente poter garantire un ulteriore innalzamento nella qualità di inquadrare clinicamente queste tre patologie vertiginose. 


\section{Introduction}

Vestibular evoked myogenic potentials (VEMPs) are short latency electromyographic responses that can be recorded from various muscles during the contraction phase in response to acoustic stimulus. VEMPs recorded from ipsilateral sternocleidomastoid muscle known as "cervical VEMP" (cVEMP) are a clinical demonstration of the vestibulo-collic reflex. cVEMP responses are characterised by biphasic waves with initial positivity (p13) followed by a negative wave (n23). The cVEMP pathway is believed to originate in the saccular macula and continues through the vestibular nerve and nucleus, vestibulospinal tracts, spinal motor nucleus and the sternocleidomastoid muscles ${ }^{1}$.

Recently, a myogenic response recorded from contralateral extraocular muscles in response to acoustic stimuli has been reported to be a manifestation of crossed vestibuloocular reflex and named "ocular VEMP" (oVEMP). The oVEMP pathway is thought to travel through the medial longitudinal fasciculus, oculomotor nuclei and nerves and extraocular muscles after the activation of the vestibular nerve and nucleus ${ }^{2}$. oVEMP responses are characterised by biphasic waves with an initial negative peak (n1) followed by a positive peak (p1) ${ }^{1}$.

The study of otolithic function in both its saccular (cVEMPs) and utricular (oVEMPs) parts represents a milestone similar to that marked by the introduction of the caloric test, as the diagnosis and prognosis of numerous vestibular diseases can be influenced by such findings ${ }^{3}$. Moreover, VEMP recording is a simple and rapid method that is well tolerated by subjects, and easily implementable in a laboratory equipped for recording evoked potentials. For these reasons, the VEMP recording test has become an important diagnostic tool, particularly in evaluation of peripheral vestibular disorders.

At present, cVEMP responses have been shown to be particularly useful in assessment of patients with "superior semicircular canal dehiscence" presenting a lower-thannormal threshold for elicitation of the cVEMP response in the affected ear ${ }^{4}$. However, VEMPs are also thought to provide useful information about brainstem functions, as the neural pathway of both VEMPs pass through the brainstem, and several studies have described cVEMP and oVEMP abnormalities in brainstem lesions ${ }^{5-7}$.

Undoubtedly, in recent years the popularity of this type of vestibular testing is on the increase, and different reports have been published about the utility of VEMPs in vestibular and otologic pathologies.

The aim of this systematic review was to define the advances of the application of VEMPs to three frequent vestibular pathologies, as outlined in the recent literature.

\section{Materials and methods}

In April 2017, a computerised MEDLINE search was performed using the PubMed service of the U.S. National Library of Medicine; the following 3 search strings were run:

1. "Ménière Disease"[Mesh] OR "Endolymphatic Hydrops"[Mesh] AND "Vestibular Evoked Myogenic Potentials"[Mesh];

2. "Vestibular Neuronitis"[Mesh] OR "Vestibular neuritis"[Mesh] AND "Vestibular Evoked Myogenic Potentials"[Mesh];

3. "Benign Paroxysmal Positional Vertigo"[Mesh] AND "Vestibular Evoked Myogenic Potentials"[Mesh].

Overall, the initial search returned a total of 140 results. Abstracts and titles obtained were screened independently by two of the authors (F.M.G. and M.R.), who subsequently met to discuss disagreements on citation inclusion.

Inclusion criteria for citations were:

- articles reporting sufficient number of patients (> 10 subjects).

Exclusion criteria for citations were:

- analysis including cohorts of patients affected by others vestibular pathologies;

- articles concerning different instrumental methods than cVEMPs or oVEMPs.

Of the 140 articles, 36 met initial inclusion criteria according to both authors (FMG and MR), and were thus obtained and reviewed in detail by the same two authors, who met and discussed disagreements on article inclusion. Inclusion criteria for full text articles identified were:

- sufficient and accurate description of VEMPs recording system;

- sufficient and accurate description of pathologies and clinical features.

Exclusion criteria were:

- lack of sufficient analysis and presentation of data;

- inclusion of patients with probable or not definite diagnosis.

A total of 12 studies were excluded because of insufficient data about recording VEMPs $(n=4)$, lack of sufficient analysis of presented data $(n=6)$, or patient redundancy $(\mathrm{n}=2)$.

An additional manual check was performed on the references included in the articles and two additional studies were identified and confirmed to meet the inclusion criteria. The main information was extracted and analysed for all included studies.

\section{Results}

After an initial check, full-text retrieval and manual cross- 


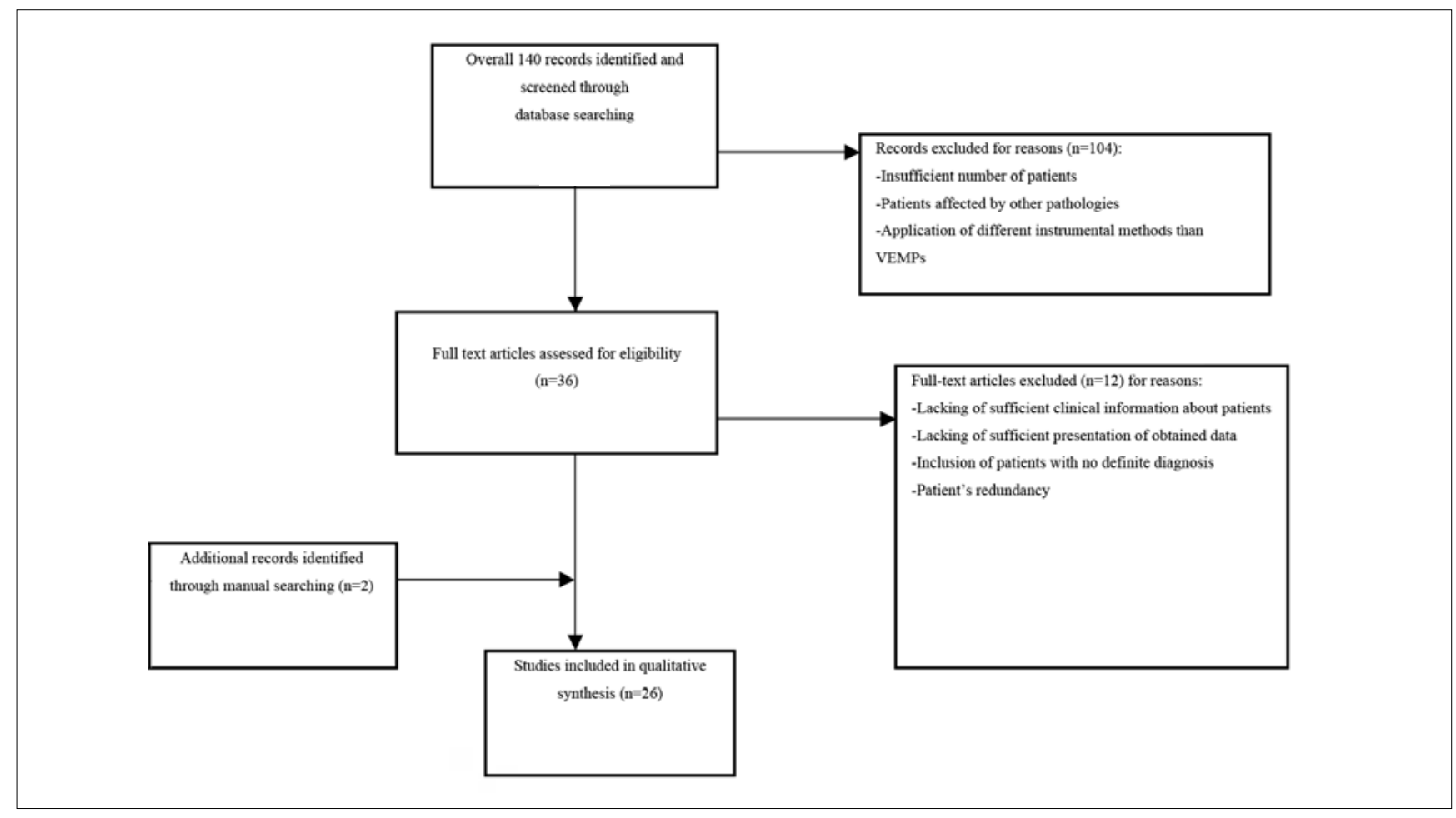

Fig. 1. Flowchart showing studies' selection.

checking of references included in the articles, a total of 26 studies, including 1181 subjects, clearly met the inclusion criteria and were chosen for analysis (Figure 1). The main characteristics of these selected studies are outlined in Tables I, II and III.

Overall, the number of patients in each study included in this analysis varied from 12 to 134 . There were 6 studies (including 296 patients) investigating VN, 10 studies (including 378 patients) dedicated to MD and 13 studies (including 507 patients) investigating BPPV.

All VN dedicated studies performed cVEMPs, while oVEMPs responses were recorded in only 3 of the studies. Of the 10 MD studies, cVEMPs was performed in 7 and oVEMPs in 3 studies. Of the 13 articles analysing BPPV patients, 8 investigated cVEMPs while only 1 study reported recording oVEMPs.

Overall, abnormal VEMPs recording rates for $\mathrm{VN}$ ranged from $36.6 \%$ to $80 \%$ (Table I). A significant correlation between the presence of VEMPs abnormalities and pathology was reported in 5 of the MD studies; amplitude reduction was the most frequently observed alteration (Table II). Furthermore, half of the BPPV articles (4/8) found a significant correlation between affected patients and VEMP abnormalities compared to control groups (Table III).

\section{Vestibular neuritis}

The vestibular nerve is composed of the superior vestibular nerve (utricular nerve and superior and lateral ampullary nerves) and the inferior vestibular nerve (saccular nerve and posterior ampullary nerve) ${ }^{8}$. Vestibular neuritis $(\mathrm{VN})$ is a clinical entity defined by an episode of prolonged vertigo associated with unilateral peripheral vestibular hypofunction ${ }^{9}$. It may affect either the entire vestibular nerve or each division of the vestibular nerve separately ${ }^{10}$.

In patients who present selective involvement of the superior vestibular nerve (superior $\mathrm{VN}$ ), the function of the horizontal and anterior canals is impaired, as shown by abnormal calorics and deficient head-impulse tests in the plane of the involved horizontal and anterior canals ${ }^{11}$.

In such patients, the utricular afferents that traverse the superior vestibular nerve are likely to have absent or reduced function. However, the function of the inferior division of the vestibular nerve is spared, as shown by normal head-impulse tests during stimulation of the posterior canal and normal cVEMP ${ }^{12} 13$.

By contrast, $\mathrm{VN}$ selectively affecting the inferior division may show reduced or absent ipsilesional cVEMP in the presence of functioning horizontal and anterior semicircular canals and utricle, as determined by normal calorics and horizontal head-impulse tests ${ }^{14}$. 
Table I. Main characteristics of the studies analysed with correlations between vestibular neuritis (VN) and VEMPs responses.

\begin{tabular}{|c|c|c|c|c|c|c|c|c|c|}
\hline Authors & Year & $\begin{array}{l}\text { No. of patients } \\
\text { with definite } \\
\text { VN }\end{array}$ & $\begin{array}{l}\text { No. of healthy } \\
\text { subjects in } \\
\text { control group }\end{array}$ & $\begin{array}{c}\text { Type } \\
\text { of VEMPs }\end{array}$ & $\begin{array}{l}\text { Sound } \\
\text { conduction }\end{array}$ & Stimuli & $\begin{array}{l}\text { Stimulation } \\
\text { intensity }\end{array}$ & $\begin{array}{l}\text { Stimulation } \\
\text { frequencies }\end{array}$ & $\begin{array}{l}\text { Significant } \\
\text { findings in VEMPs } \\
\text { responses }\end{array}$ \\
\hline Hong et al. ${ }^{17}$ & 2008 & 134 & None & cVEMP & ACS & Clicks & $95 \mathrm{~dB}$ & $2,000 \mathrm{~Hz}$ & $\begin{array}{l}\text { Abnormal values in } \\
49(36.6 \%) \text { patients }\end{array}$ \\
\hline $\begin{array}{l}\text { Vinciana and } \\
\text { Lopez-Escamez }^{18}\end{array}$ & 2010 & 41 & None & cVEMP & ACS & Tone bursts & $129 \mathrm{~dB}$ & $500 \mathrm{~Hz}$ & $\begin{array}{l}\text { Abnormal values in } \\
21(51 \%) \text { patients }\end{array}$ \\
\hline Nola et al. ${ }^{19}$ & 2011 & 20 & None & cVEMP & ACS & n.a. & $130 \mathrm{~dB}$ & $500 \mathrm{~Hz}$ & $\begin{array}{c}\text { Abnormal values in } \\
9(45 \%) \text { patients }\end{array}$ \\
\hline \multirow[t]{2}{*}{ Shin et al. ${ }^{14}$} & 2012 & 41 & 60 & cVEMP & ACS & Tone bursts & $100 \mathrm{~dB}$ & $1,000 \mathrm{~Hz}$ & n.a. \\
\hline & & & & OVEMP & ACS & Tone bursts & $100 \mathrm{~dB}$ & $1,000 \mathrm{~Hz}$ & $\begin{array}{l}\text { Abnormal values in } \\
30(73.1 \%) \text { patients }\end{array}$ \\
\hline \multirow[t]{2}{*}{$\begin{array}{l}\text { Walther and } \\
\text { Blodow }{ }^{20}\end{array}$} & 2013 & 20 & None & cVEMP & ACS & Tone bursts & $100 \mathrm{~dB}$ & $500 \mathrm{~Hz}$ & $\begin{array}{c}\text { Abnormal values in } \\
9(45 \%) \text { patients }\end{array}$ \\
\hline & & & & oVEMP & ACS & Tone bursts & $100 \mathrm{~dB}$ & $500 \mathrm{~Hz}$ & $\begin{array}{c}\text { Abnormal values in } \\
12(60 \%) \text { patients }\end{array}$ \\
\hline \multirow[t]{2}{*}{ Magliulo et al. ${ }^{3}$} & 2014 & 40 & None & cVEMP & ACS & Logon & $130 \mathrm{~dB}$ & $500 \mathrm{~Hz}$ & $\begin{array}{l}\text { Abnormal values in } \\
19(47.5 \%) \text { patients }\end{array}$ \\
\hline & & & & oVEMP & BCS & n.a. & n.a. & n.a. & $\begin{array}{l}\text { Abnormal values in } \\
32(80 \%) \text { patients }\end{array}$ \\
\hline
\end{tabular}

ACS: Air-Conducted Sound; BCS: Bone-Conducted Sound; n.a.: not available.

Functional impairment of the entire vestibular nerve (superior and inferior division) and a single superior division involvement in $\mathrm{VN}$ are the most common conditions ${ }^{15}$, and selective inferior vestibular nerve damage has recently been described ${ }^{16}$.

Some authors have investigated the role of VEMPs recording in improving the diagnostic accuracy for patients affected by VN. Hong et al. ${ }^{17}$ studied 134 patients with VN. Overall 49 (36.6\%) showed an abnormal cVEMP response. In particular, a prolonged p13 latency was noted in 29 patients, while 25 patients presented a n23 prolonged latency. Increased cVEMP asymmetry was found in 27 patients. The authors speculated that $36.6 \%$ of all subjects in their study had lesions in the labyrinth or inferior vestibular nerve.

Vinciana et al. ${ }^{18}$ analysed 41 patients diagnosed with VN. cVEMPs were performed and resulted abnormal in 21 $(51 \%)$ of 41 cases, the most common finding was an increase in ipsilateral latencies for $\mathrm{p} 1$ and $\mathrm{n} 1$ peaks.

Further, Nola et al. ${ }^{19}$ performed cVEMP recording in a cohort of 20 patients affected by VN. Nine patients, presenting a torsional nystagmus and bilateral normoreflexia after caloric labyrinth stimulation, had no cVEMP response on the affected side (while the response was present on the contralateral side). The authors concluded that these nine patients were affected by inferior VN.

The cVEMP examinations were then repeated after 8 days, 1 month and 3 months. After 8 days, seven of the patients diagnosed with inferior branch $\mathrm{VN}$ showed an improve- ment of cVEMP values while a complete reappearance of cVEMP after 1 month was noted in all nine patients.

The findings of Shin et al. ${ }^{14}$ strongly support the hypothesis that oVEMPs response is mediated by the superior vestibular nerve. The authors examined 41 patients with acute $\mathrm{VN}$, and on the basis of clinical findings (appearance of mixed horizontal and torsional nystagmus; impaired horizontal SCC function on head-impulse test and caloric paresis $>25 \%$; normal cVEMP and normal headimpulse test for posterior SCC) 30 subjects affected by neuritis of the superior vestibular nerve were identified. Interestingly, all these patients presented normal cVEMP responses in the affected ear, indicating that the saccular otolithic receptors and their afferents, in the inferior vestibular nerve, were completely functional. In contrast, all 30 patients had an asymmetric oVEMP response with the p10 component either absent, markedly reduced or delayed, beneath the eye opposite to the affected ear.

In a recent study, Magliulo et al. ${ }^{3}$ prospectively evaluated 40 patients affected by VN employing both cVEMPs and oVEMPs. Thirty-two of the 40 patients showed absent or abnormal oVEMPs at the first control, while only 19 of the 40 patients showed absent or abnormal values of cVEMPs. With the aid of the video head impulse test (vHIT) the authors were able to classify the various pathological findings with regards to the location of vestibular damage and number of vestibular organs involved. The superior vestibular nerve VN (30\%), followed by the total VN (25\%), were the most frequently involved entities. 
Table II. Main characteristics of the studies analysed with correlations between Ménière's disease (MD) and VEMPs responses.

\begin{tabular}{|c|c|c|c|c|c|c|c|c|c|}
\hline Authors & Year & $\begin{array}{l}\text { No. of patients } \\
\text { with definite } \\
\text { MD }\end{array}$ & $\begin{array}{l}\text { No. of healthy } \\
\text { subjects in the } \\
\text { control group }\end{array}$ & $\begin{array}{l}\text { Type } \\
\text { of VEMPs }\end{array}$ & $\begin{array}{l}\text { Sound } \\
\text { conduction }\end{array}$ & Stimuli & $\begin{array}{l}\text { Stimulation } \\
\text { intensity }\end{array}$ & $\begin{array}{l}\text { Stimulation } \\
\text { frequencies }\end{array}$ & $\begin{array}{l}\text { Significant } \\
\text { findings in VEMPs } \\
\text { responses }\end{array}$ \\
\hline Akkuzu et al. ${ }^{34}$ & 2006 & 20 & 17 & cVEMP & ACS & Tone bursts & $100 \mathrm{~dB}$ & $500 \mathrm{~Hz}$ & $\begin{array}{l}\text { Abnormal values } \\
\quad(p<0.001)\end{array}$ \\
\hline Hong et al. ${ }^{17}$ & 2008 & 29 & None & cVEMP & ACS & Clicks & $95 \mathrm{~dB}$ & $2,000 \mathrm{~Hz}$ & $\begin{array}{l}\text { Abnormal values in } \\
20(69 \%) \text { patients }\end{array}$ \\
\hline Kim-Lee et al. ${ }^{42}$ & 2009 & 24 & 20 & cVEMP & ACS & Tone bursts & $90 \mathrm{~dB}$ & $500-1,000 \mathrm{~Hz}$ & $\begin{array}{l}\text { Elevated frequency } \\
\text { peak amplitude } \\
(p<0.001)\end{array}$ \\
\hline \multirow[t]{3}{*}{ Winters et al. ${ }^{37}$} & 2011 & 37 & 55 & OVEMP & ACS & Tone bursts & $120 \mathrm{~dB}$ & $500-4,900 \mathrm{~Hz}$ & $\begin{array}{l}\text { Lower response } \\
\text { rate }(p<0.05)\end{array}$ \\
\hline & & & & & & & & & $\begin{array}{l}\text { Higher asymmetry } \\
\text { ratio }(p<0.05)\end{array}$ \\
\hline & & & & & & & & & $\begin{array}{l}\text { Lower amplitude } \\
\qquad(p<0.05)\end{array}$ \\
\hline $\begin{array}{l}\text { Kingma and } \\
\text { Wit }^{36}\end{array}$ & 2011 & 22 & None & cVEMP & ACS & Tone bursts & $100 \mathrm{~dB}$ & $250-500 \mathrm{~Hz}$ & $\begin{array}{l}\text { Lower amplitude in } \\
\text { the affected ears } \\
\quad(p<0.05)\end{array}$ \\
\hline \multirow[t]{4}{*}{ Taylor et al. ${ }^{38}$} & 2011 & 60 & 35 & cVEMP & ACS & Clicks & $140 \mathrm{~dB}$ & $500 \mathrm{~Hz}$ & $\begin{array}{c}\text { Abnormal values in } \\
24(40 \%) \text { patients }\end{array}$ \\
\hline & & & & & BCS & $\begin{array}{l}\text { Vibration } \\
\text { pulses }\end{array}$ & n.a. & n.a. & $\begin{array}{l}\text { Abnormal values } \\
\text { in } 13 \\
(22.8 \%) \text { patients }\end{array}$ \\
\hline & & & & OVEMP & ACS & Clicks & $140 \mathrm{~dB}$ & $500 \mathrm{~Hz}$ & $\begin{array}{l}\text { Abnormal values in } \\
30(50 \%) \text { patients }\end{array}$ \\
\hline & & & & & BCS & $\begin{array}{l}\text { Vibration } \\
\text { pulses }\end{array}$ & n.a. & n.a. & $\begin{array}{l}\text { Abnormal values in } \\
6(10.2 \%) \text { patients }\end{array}$ \\
\hline \multirow[t]{2}{*}{ Sandhu et al. ${ }^{41}$} & 2012 & 12 & 8 & cVEMP & ACS & Tone bursts & $120 \mathrm{~dB}$ & $\begin{array}{c}250-500-750- \\
1,000-1,500- \\
2,000-3,000- \\
4,000 \mathrm{~Hz}\end{array}$ & $\begin{array}{l}\text { Lower amplitude } \\
\qquad(p<0.05)\end{array}$ \\
\hline & & & & oVEMP & ACS & Tone bursts & $120 \mathrm{~dB}$ & $250-4,000 \mathrm{~Hz}$ & $\begin{array}{l}\text { Lower amplitude } \\
\qquad(p<0.05)\end{array}$ \\
\hline Egami et al. ${ }^{35}$ & 2013 & 114 & None & cVEMP & ACS & $\begin{array}{l}\text { Clicks/ } \\
\text { Tone bursts }\end{array}$ & $95 \mathrm{~dB}$ & $500 \mathrm{~Hz}$ & $\begin{array}{c}\text { Abnormal values in } \\
57(50 \%) \text { patients }\end{array}$ \\
\hline Silva et al. ${ }^{61}$ & 2016 & 30 & 30 & $\begin{array}{l}\text { Combined } \\
\text { cVEMP- } \\
\text { oVEMP }\end{array}$ & ACS & Tone bursts & $120 \mathrm{~dB}$ & $500 \mathrm{~Hz}$ & $\begin{array}{l}\text { Mean latency } \\
\text { values of } n 10 \text { - } \\
\text { p15 waves were } \\
\text { higher than } \\
\text { control group }\end{array}$ \\
\hline \multirow[t]{2}{*}{ Chen et al. ${ }^{62}$} & 2016 & 30 & 30 & cVEMP & ACS & Tone bursts & $90 \mathrm{~dB}$ & $500 \mathrm{~Hz}$ & $\begin{array}{l}\text { Abnormal } \\
\text { responses in } 12 \\
(40 \%) \text { patients }\end{array}$ \\
\hline & & & & OVEMP & ACS & Tone bursts & $95 \mathrm{~dB}$ & $500 \mathrm{~Hz}$ & $\begin{array}{c}\text { Abnormal } \\
\text { responses in } 5 \\
(16.7 \%) \text { patients }\end{array}$ \\
\hline
\end{tabular}

ACS: Air-Conducted Sound; BCS: Bone-Conducted Sound; n.a.: not available.

Similary, Walther and Blodow ${ }^{20}$ analysed 20 patients affected by VN using both oVEMPs and cVEMPs in combination with vHIT. The authors were able to differentiate 4 types of VN (entire VN; superior VN; inferior VN; ampullary $\mathrm{VN}$ ); entire $\mathrm{VN}$ and superior $\mathrm{VN}$ were the entities most frequently observed.
Ménière's disease (MD)

Ménière's disease (MD) is characterised by fluctuating hearing loss, tinnitus, aural fullness and episodic vertigo ${ }^{21} 22$. The histopathological correlate, endolymphatic hydrops, is observed most frequently in the cochlea and the saccule, followed by the utricle and the semi-circular canals ${ }^{23-25}$. 
Table III. Main characteristics of the studies analysed with correlations between benign paroxysmal positional vertigo (BPPV) and VEMPs responses.

\begin{tabular}{|c|c|c|c|c|c|c|c|c|c|}
\hline Authors & Year & $\begin{array}{l}\text { No. of patients } \\
\text { with definite } \\
\text { BPPV }\end{array}$ & $\begin{array}{l}\text { No. of healthy } \\
\text { subjects in } \\
\text { control group }\end{array}$ & $\begin{array}{l}\text { Type } \\
\text { of VEMPs }\end{array}$ & $\begin{array}{l}\text { Sound } \\
\text { conduction }\end{array}$ & Stimuli & $\begin{array}{l}\text { Stimulation } \\
\text { intensity }\end{array}$ & $\begin{array}{l}\text { Stimulation } \\
\text { frequencies }\end{array}$ & $\begin{array}{l}\text { Significant findings } \\
\text { and correlations in } \\
\text { VEMPs responses }\end{array}$ \\
\hline Akkuzu et al. ${ }^{34}$ & 2006 & 25 & 17 & cVEMP & ACS & Tone bursts & $500 \mathrm{~dB}$ & $500 \mathrm{~Hz}$ & $\begin{array}{l}\text { Abnormal values } \\
\quad(p=0.012)\end{array}$ \\
\hline $\begin{array}{l}\text { Boleas-Aguirre } \\
\text { et al. } 50\end{array}$ & 2007 & 19 & None & cVEMP & ACS & Clicks & $70-100 \mathrm{~dB}$ & n.a. & $\begin{array}{c}\text { Absent responses in } \\
10(52.4 \%) \text { affected } \\
\text { ears vs } 5(26.3 \%) \\
\text { healthy ears }\end{array}$ \\
\hline Hong et al. ${ }^{17}$ & 2008 & 62 & None & cVEMP & ACS & Clicks & $95 \mathrm{~dB}$ & $500 \mathrm{~Hz}$ & $\begin{array}{l}\text { Abnormal values in } \\
24(40 \%) \text { patients }\end{array}$ \\
\hline Yang et al. ${ }^{51}$ & 2008 & 41 & 92 & cVEMP & ACS & Clicks & $95 \mathrm{~dB}$ & n.a. & $\begin{array}{l}\text { No response in } 11 \\
(27 \%) \text { patients; } \\
\text { Prolonged latencies } \\
\quad(p<0.001)\end{array}$ \\
\hline Korres et al. ${ }^{52}$ & 2011 & 27 & 30 & cVEMP & ACS & Tone bursts & $95 \mathrm{~dB}$ & $500 \mathrm{~Hz}$ & $\begin{array}{l}\text { Abnormal values } \\
\quad(p<0.005)\end{array}$ \\
\hline Longo et al. ${ }^{55}$ & 2011 & 23 & 24 & cVEMP & ACS & Logon & $127 \mathrm{~dB}$ & $500 \mathrm{~Hz}$ & $\begin{array}{l}\text { Abnormal values } \\
\qquad(p<0.001)\end{array}$ \\
\hline \multirow[t]{2}{*}{ Lee et al. ${ }^{53}$} & 2013 & 16 & None & cVEMP & ACS & Tone bursts & $90 \mathrm{~dB}$ & $500 \mathrm{~Hz}$ & $\begin{array}{c}\text { Abnormal values in } \\
5(31.3 \%) \text { patients }\end{array}$ \\
\hline & & & & oVEMP & ACS & Tone bursts & $95 \mathrm{~dB}$ & $500 \mathrm{~Hz}$ & $\begin{array}{c}\text { Abnormal values in } \\
4(25 \%) \text { patients }\end{array}$ \\
\hline Yetiser et al. ${ }^{54}$ & 2014 & 102 & 15 & cVEMP & ACS & Tone bursts & $95 \mathrm{~dB}$ & $500 \mathrm{~Hz}$ & $\begin{array}{l}\text { Abnormal values in } \\
24(23.5 \%) \text { patients }\end{array}$ \\
\hline \multirow[t]{2}{*}{ Xu et al. ${ }^{56}$} & 2016 & 30 & 30 & cVEMP & ACS & Tone bursts & $90 \mathrm{~dB}$ & $500 \mathrm{~Hz}$ & $\begin{array}{c}\text { Abnormal values } \\
\text { in } 9(30 \%) \text { BPPV } \\
\text { patients vs } 2(6.6 \%) \\
\text { healthy patients }\end{array}$ \\
\hline & & & & oVEMP & ACS & Tone bursts & $95 \mathrm{~dB}$ & $500 \mathrm{~Hz}$ & $\begin{array}{c}\text { Abnormal values in } \\
17(56.7 \%) \text { BPPV } \\
\text { patients vs } 1 \text { (3.3\%) } \\
\text { healthy patient }\end{array}$ \\
\hline \multirow[t]{2}{*}{ Singh et al. ${ }^{57}$} & 2015 & 31 & 31 & cVEMP & ACS & Tone bursts & $125 \mathrm{~dB}$ & $500 \mathrm{~Hz}$ & $\begin{array}{l}\text { No significant group } \\
\text { difference on any } \\
\text { cVEMP parameters }\end{array}$ \\
\hline & & & & OVEMP & ACS & Tone bursts & $125 \mathrm{~dB}$ & $500 \mathrm{~Hz}$ & $\begin{array}{c}\text { Peak-to-peak } \\
\text { amplitude } \\
\text { significantly smaller } \\
\text { in the affected ears }\end{array}$ \\
\hline Chang et al. ${ }^{58}$ & 2017 & 65 & None & cVEMP & ACS & Tone bursts & $95 \mathrm{~dB}$ & $500 \mathrm{~Hz}$ & $\begin{array}{l}\text { Decreased interaural } \\
\text { amplitude difference } \\
\text { ratio at the affect } \\
\text { side associated with } \\
\text { persisting BPPV } \\
\text { after manoeuver }\end{array}$ \\
\hline $\begin{array}{l}\text { Hoseinabadi } \\
\text { et al. }{ }^{59}\end{array}$ & 2015 & 30 & None & $\begin{array}{l}\text { CVEMP } \\
\text { OVEMP }\end{array}$ & ACS & Tone bursts & $95 \mathrm{~dB}$ & $500 \mathrm{~Hz}$ & $\begin{array}{c}\text { QoL is more } \\
\text { compromised } \\
\text { in patients with } \\
\text { cVEMP and oVEMP } \\
\text { abnormalities }\end{array}$ \\
\hline Karatas et al. ${ }^{60}$ & 2016 & 36 & 20 & cVEMP & ACS & Tone bursts & $100 \mathrm{~dB}$ & $500 \mathrm{~Hz}$ & $\begin{array}{l}\text { Normalised } \\
\text { amplitudes of BPPV } \\
\text { patients significantly } \\
\text { lower than those in } \\
\text { the control group }\end{array}$ \\
\hline
\end{tabular}


The diagnosis of MD relies upon clinical presentation and pure tone audiometry, which in the early stages of the disease shows low frequency hearing loss in a "rising configuration" that later progresses to a flat hearing loss of moderate severity ${ }^{26-29}$.

Current standard vestibular testing consists of caloric stimulation of both ears using nystagmography to evaluate the ear's functionality. However, this test highlights disturbances in only 1 (the horizontal canal) of the 3 semicircular canals. Moreover, in patients with MD, the calorigram can show variable responses, and in many cases, test results are normal ${ }^{30}$.

Initial reports using a standard fixed acoustic stimulus showed that a significant number $(35 \%-54 \%)$ of patients with MD did not have cVEMPs present ${ }^{31-33}$, so that authors began to compare VEMPs values in patients affected by MD with those recorded in normal ears.

Akkuzu et al. ${ }^{34}$ found 10 (50\%) abnormal cVEMP responses in 20 patients with MD. In particular, there were 4 ears with no response while six ears presented a prolonged latency at p13. Among 29 subjects diagnosed with MD, Hong et al. ${ }^{15}$ observed an abnormality of cVEMP in $20(69 \%)$ of them. In particular, increased cVEMP asymmetry was noted in $14(70 \%)$ patients followed by a prolonged p13 latency ( 9 patients, $45 \%$ ).

Egami et al. ${ }^{35}$ measuring cVEMP in 144 patients affected by MD and found abnormal values in $57(50 \%)$ of them. It must be noted that among the same patients only 43 $(37.7 \%)$ showed no or decreased caloric responses on the affected side.

Kingma et al. ${ }^{36}$ measured cVEMP in 22 patients affected by MD. On average, significantly lower VEMP amplitudes were measured at the side of the affected ear for both stimulus frequencies $(250$ and $500 \mathrm{~Hz}$ ).

Winters et al. ${ }^{37}$ evaluated the changes of the oVEMP in a group of 37 patients with MD. The data showed that the oVEMP response rates in ears of patients with MD were dramatically lower (54\% at $120 \mathrm{~dB}$ SPL; $29 \%$ at $115 \mathrm{~dB}$ SPL) than in normal subjects (98.2\% at $120 \mathrm{~dB}$ SPL). Taylor et al. ${ }^{38}$ investigated the prevalence of cVEMP and oVEMP on 60 patients with MD reporting 50\% of abnormality for oVEMP and $40 \%$ of abnormality for cVEMP responses.

Some authors ${ }^{39}{ }^{40}$ reported a shift in dominant frequency away from the typical 500 to $1000 \mathrm{~Hz}$ for VEMPs recorded in patients with MD. On the basis of these observations, Sandhu et al. ${ }^{41}$ confirmed the presence of this shift in dominant frequency for both cVEMP and oVEMP in patients with MD. Interestingly, the authors were able to evoke myogenic potentials in all ears tested: in healthy volunteers, the acoustic stimulus frequency at which the response amplitudes were largest was $500 \mathrm{~Hz}$, while in subjects affected by MD this value shifted to higher frequencies.

Similar results were observed by Kim-Lee et al. ${ }^{42}$ who analysed the cVEMP responses in a group of 24 subjects with MD. Overall, cVEMP were present in $83 \%$ of affected ears, but were most reliably elicited at a tone burst stimulation frequency of $1,000 \mathrm{~Hz}$. Moreover, the frequency peak amplitude ratios (FPA) in the MD group were significantly elevated compared with those of the control group. The authors concluded that FPA is elevated in MD and thus may represent a useful diagnostic criterion in the diagnosis of this pathology.

Another interesting study was published by Katayama et al. ${ }^{43}$ who investigated the relationship between the presence of endolymphatic hydrops and cVEMP in patients with MD. Intratympanic injection with gadolinium diluted with saline was performed in 49 affected ears and after one day, 3 Tesla MRI and cVEMP were performed. Overall, cVEMP was present in 21 ears and absent in 28 ears. Endolymphatic hydrops was significantly associated with the absence of cVEMP.

\section{Benign paroxysmal positional vertigo (BPPV)}

Benign paroxysmal positional vertigo (BPPV) is the most common disorder of the peripheral vestibular system and characterised by episodes of vertigo associated with head movements ${ }^{44} 45$. Although BPPV generally responds well to treatment, there is a significant rate of recurrence after the initial resolution ${ }^{46}$. The recurrence rates during a 1 -year follow-up period have been reported to range from $10 \%$ to $18 \%{ }^{4748}$.

In explaining the pathophysiology of BPPV, the concept of a degenerative process that affects the macula of the utricle causing detachment of otoliths has gained popular support ${ }^{49}$. However, in 30 affected ears with BPPV Akkuzu et al. ${ }^{34}$ found 9 (30\%) ears showing abnormal cVEMP values. This finding suggested that the degenerative process involved in BPPV might also affect the macula of the saccule.

Similarly, Boleas-Aguirre et al. ${ }^{50}$ analysed 19 patients diagnosed with BPPV of the posterior semi-circular canal. The authors found a lack of cVEMP response in 52\% of the affected ears. When adjusted for bilateral absence, cVEMP response was absent in $20.3 \%$ of ears. The authors concluded that some patients with BPPV show a certain degree of saccular dysfunction.

Among 62 subjects diagnosed with BPPV, Hong et al. ${ }^{15}$ reported an abnormality of cVEMP in $16(25.8 \%)$ of them. Yang et al. ${ }^{51}$ investigated the clinical significance of cVEMP in a group of 41 patients affected by BPPV 
in comparison to 92 healthy volunteers. Overall, 11 (27\%) patients in the BPPV group showed no response in VEMPs in the affected ear. Moreover, VEMPs showed prolonged $\mathrm{p} 13$ and $\mathrm{n} 23$ latencies in BPPV subjects compared with those of the control group.

Korres et al. ${ }^{52}$ analysed $27 \mathrm{BPPV}$ patients and noted that the percentage of abnormal cVEMP in the BPPV population was significantly higher than in the ears of control group.

Lee et al. ${ }^{53}$ investigated the usefulness of VEMP in patients presenting recurrent BPPV and reported interesting results. The authors analysed 16 subjects presenting recurrent BPPV and 20 patients with non-recurrent BPPV by cVEMP and oVEMP. Among the group of patients with recurrent BPPV, abnormal cVEMP responses were detected in $5(31.3 \%)$ subjects, while abnormal oVEMP responses resulted in $4(25 \%)$ subjects. Between the 20 patients with non-recurrent BPPV, only $3(15 \%)$ subjects overall showed abnormal cVEMP or abnormal oVEMP. Yetiser et al. ${ }^{54}$ recently analysed a cohort of 102 patients affected by BPPV and reported similar findings. In total, $24(23.5 \%)$ patients presented a gross cVEMP abnormality (absence of VEMP in 6 and greater than 25\% depression of the amplitude in 18). Abnormality of VEMPs was not correlated with age, severity of nystagmus or the site of canal involvement, but was significantly correlated with persistence or recurrence of symptoms.

Finally, Longo et al. ${ }^{55}$, in their prospective study of 23 patients affected by BPPV and 24 healthy volunteers, found that the cVEMP among BPPV patients were altered in 14 ears $(30.4 \%)$ and absent in $5(10.9 \%)$ affected ears and in $2(4.3 \%)$ non-affected ears. This value was significantly higher than the comparative control groups.

\section{Conclusions}

Although official standard measurement parameters of normality must still be defined for VEMPs, it seems clear that this instrument will represent a novel and important vestibular examination for VP, MD and BPPV. In VN, VEMPs (cVEMP together with oVEMP) may represent a useful tool in improving topographic diagnosis, offering key information about prognosis and therapy. In MD, both cVEMP and oVEMP showed better sensitivity and specificity compared with the caloric test, but a wide variety of described alterations in VEMPs recordings among the studies analysed were noted, with amplitude reduction representing the most frequent finding. For this reason, additional studies are needed to accurately identify specific anomalies in VEMPs recording associated with MD. In VPPB, VEMPs may also be important in predicting pathological recurrences.

\section{Conflict of interest statement}

None declared.

\section{References}

1 Gazioglu S, Boz C. Ocular and cervical vestibular evoked myogenic potentials in multiple sclerosis patients. Clin Neurophysiol 2012;123:1872-9. https://doi.org/10.1016/j.clinph.2012.01.022.

2 Rosengren SM, Welgampola MS, Colebatch JG. Vestibular evoked myogenic potentials: past, present and future. Clin Neurophysiol 2010;121:636-51. https://doi.org/10.1016/j.clinph.2009.10.016.

3 Magliulo G, Iannella G, Gagliardi S, et al. A 1-year follow-up study with $C$-VEMPs, $O$-VEMPs and video head impulse testing in vestibular neuritis. Eur Arch Otorhinolaryngol 2015;272:3277-81. https:// doi.org/10.1007/s00405-014-3404-9.

4 Re M, Gioacchini FM, Salvolini U, et al. Multislice computed tomography overestimates superior semicircular canal dehiscence syndrome. Ann Otol Rhinol Laryngol 2013;122:625-31.

5 Su CH, Young YH. Differentiating cerebellar and brainstem lesions with ocular vestibular-evoked myogenic potential test. Eur Arch Otorhinolaryngol 2011;268:923-30. https://doi.org/10.1007/ s00405-010-1463-0.

6 Itoh A, Kim YS, Yoshioka K, et al. Clinical study of vestibularevoked myogenic potentials and auditory brainstem responses in patients with brainstem lesions. Acta Otolaryngol 2001;545:116-9.

7 Pollak L, Kushnir M, Stryjer R. Diagnostic value of vestibular evoked myogenic potentials in cerebellar and lower-brainstem strokes. Neurophysiol Clin 2006;36:227-33. https://doi.org/10.1016/j. neucli.2006.08.014.

8 Le TN, Westerberg BD, Lea J. Vestibular neuritis: recent advances in etiology, diagnostic evaluation, and treatment. Adv Otorhinolaryngol 2019;82:87-92. https://doi.org/10.1159/000490275.

9 Strupp M, Brandt T. Vestibular neuritis. Semin Neurol 2009;29:50919. https://doi.org/10.1055/s-0029-1241040.

10 Aw ST, Fetter M, Cremer PD, et al. Individual semicircular canal function in superior and inferior vestibular neuritis. Neurology 2001;57:768-74. https://doi.org/10.1212/wnl.57.5.768.

11 Halmagyi GM, Curthoys IS. A clinical sign of canal paresis. Arch Neurol 1988;45:737-9. https://doi.org/10.1001/ archneur.1988.00520310043015.

12 Welgampola MS. Evoked potential testing in neuro-otology. Curr Opin Neurol 2008;21:29-35. https://doi.org/10.1097/ WCO.0b013e3282f39184.

13 Rosengren SM, Colebatch JG, Young AS, et al. Vestibular evoked myogenic potentials in practice: methods, pitfalls and clinical applications. Clin Neurophysiol Pract 2019;4:47-68. https://doi. org/10.1016/j.cnp.2019.01.005.

14 Shin BS, Oh SY, Kim JS, et al. Cervical and ocular vestibular-evoked myogenic potentials in acute vestibular neuritis. Clin Neurophysiol 2012;123:369-75. https://doi.org/10.1016/j.clinph.2011.05.029.

15 Lesmas Navarro MJ, Perez Garrigues H, Morera Perez C, et al. Contribution of the vestibular evoked myogenic potentials to the study of the vestibular neuritis. Acta Otorrinolaringol Esp 2009;60:49-5.

16 Zhang D, Fan Z, Han Y, et al. Inferior vestibular neuritis: a novel subtype of vestibular neuritis. J Laryngol Otol 2010;124:477-81. https://doi.org/10.1017/S0022215109992337.

17 Hong SM, Yeo SG, Kim SW, et al. The results of vestibular evoked myogenic potentials, with consideration of age-related changes, in vestibular neuritis, benign paroxysmal positional vertigo, and 
Ménière's disease. Acta Otolaryngol 2008;128:861-5. https://doi. org/10.1080/00016480701784981.

18 Viciana D, Lopez-Escamez JA. Vestibular evoked myogenic potentials and health-related quality of life in patients with vestibular neuritis. Otol Neurotol 2010;31:954-8.

19 Nola G, Guastini L, Crippa B, et al. Vestibular evoked myogenic potential in vestibular neuritis. Eur Arch Otorhinolaryngol 2011;268:1671-7. https://doi.org/10.1007/s00405-011-1592-0.

20 Walther LE, Blödow A. Ocular vestibular evoked myogenic potential to air conducted sound stimulation and video head impulse test in acute vestibular neuritis. Otol Neurotol 2013;34:1084-9. https:// doi.org/10.1097/MAO.0b013e318280da47.

21 Hamid MA. Ménière's disease. Pract Neurol 2009;9:157-62. https:// doi.org/10.1136/jnnp.2009.176602.

22 Phillips JS, Murdin L, Rea P, et al. Clinical subtyping of Ménière's disease. Otolaryngol Head Neck Surg 2018;159:407-9. https://doi. org/10.1177/0194599818773077.

23 Okuno T, Sando I. Localization, frequency and severity of endolymphatic hydrops and the pathology of the labyrinthine membrane in Ménière's disease. Ann Otol Rhinol Laryngol 1987;96:438-45. https://doi.org/10.1177/000348948709600418.

24 Paparella MM. The cause (multifactorial inheritance) and pathogenesis (endolymphatic malabsorption) of Ménière's disease and its symptoms (mechanical and chemical). Acta Otolaryngol 1985;99:445-51. https://doi.org/10.3109/00016488509108936.

25 Oberman BS, Patel VA, Cureoglu S, et al. The aetiopathologies of Ménière's disease: a contemporary review. Acta Otorhinolaryngol Ital 2017;37:250-63. https://doi.org/10.14639/0392-100X-793.

26 Sajjadi H, Paparella MM. Ménière's disease. Lancet 2008;372:40614. https://doi.org/10.1016/S0140-6736(08)61161-7.

$27 \mathrm{Wu} \mathrm{V}$, Sykes EA, Beyea MM, et al. Approach to Ménière disease management. Can Fam Physician 2019;65:463-7.

28 Scarpa A, Ralli M, Cassandro C, et al. Low-dose intratympanic gentamicin administration for unilateral Ménière's disease using a method based on clinical symptomatology: Preliminary results. Am J Otolaryngol 2019 Sep 9:102289. https://doi.org/10.1016/j.amjoto.2019.102289 [epub ahead of print].

29 Casani AP, Guidetti G, Schoenhuber R; Consensus Conference Group. Report from a Consensus Conference on the treatment of Ménière's disease with betahistine: rationale, methodology and results. Acta Otorhinolaryngol Ital 2018;38:460-7. https://doi. org/10.14639/0392-100X-2035.

30 Maire R, van Melle G. Vestibulo-ocular reflex characteristics in patients with unilateral Ménière's disease. Otol Neurotol 2008;29:6938. https://doi.org/10.1097/MAO.0b013e3181776703.

31 de Waele C, Huy PT, Diard JP, et al. Saccular dysfunction in Ménière's disease. Am J Otol 1999;20:223-32.

32 Murofushi T, Matsuzaki M, Takegoshi H. Glycerol affects vestibular evoked myogenic potentials in Ménière's disease. Auris Nasus Larynx 2001;28:205-8. https://doi.org/10.1016/s03858146(01)00058-x.

$33 \mathrm{Xu}$ M, Chen ZC, Wei XY, et al. [Evaluation of vestibular evoked myogenic potential, caloric test and cochlear electrogram in the diagnosis of Ménière's disease]. Lin Chung Er Bi Yan Hou Tou Jing Wai Ke Za Zhi 2019;33:704-8. https://doi.org/10.13201/j. issn.1001-1781.2019.08.006.

34 Akkuzu G, Akkuzu B, Ozluoglu LN. Vestibular evoked myogenic potentials in benign paroxysmal positional vertigo and Ménière's disease. Eur Arch Otorhinolaryngol 2006;263:510-7. https://doi. org/10.1007/s00405-005-0002-x.

35 Egami N, Ushio M, Yamasoba T, et al. The diagnostic value of vestibular evoked myogenic potentials in patients with Ménière's disease. J Vestib Res 2013;23:249-57. https://doi.org/10.3233/VES130484.

36 Kingma CM, Wit HP. Asymmetric vestibular evoked myogenic potentials in unilateral Ménière patients. Eur Arch Otorhinolaryngol 2011;268:57-61. https://doi.org/10.1007/s00405010-1345-5.

37 Winters SM, Campschroer T, Grolman W, et al. Ocular vestibular evoked myogenic potentials in response to air-conducted sound in Ménière's disease. Otol Neurotol 2011;32:1273-80. https://doi. org/10.1097/MAO.0b013e31822e5ac9.

38 Taylor RL, Wijewardene AA, Gibson WP, et al. The vestibular evoked-potential profile of Ménière's disease. Clin Neurophysiol 2011;122:1256-63. https://doi.org/10.1016/j.clinph.2010.11.009.

39 Rauch SD, Zhou G, Kujawa SG, et al. Vestibular evoked myogenic potentials show altered tuning in patients with Ménière's disease. Otol Neurotol 2004;25:333-8.

40 Node M, Seo T, Miyamoto A, et al. Frequency dynamics shift of vestibular evoked myogenic potentials in patients with endolymphatic hydrops. Otol Neurotol 2005;26:1208-13.

41 Sandhu JS, Low R, Rea PA, et al. Altered frequency dynamics of cervical and ocular vestibular evoked myogenic potentials in patients with Ménière's disease. Otol Neurotol 2012;33:444-9. https://doi. org/10.1097/MAO.0b013e3182488046.

42 Kim-Lee Y, Ahn JH, Kim YK, et al. Tone burst vestibular evoked myogenic potentials: diagnostic criteria in patients with Ménière's disease. Acta Otolaryngol 2009;129:924-8. https://doi. org/10.1080/00016480802495412.

43 Katayama N, Yamamoto M, Teranishi M, et al. Relationship between endolymphatic hydrops and vestibular-evoked myogenic potential. Acta Otolaryngol 2010;130:917-23. https://doi. org/10.3109/00016480903573187.

44 Marcelli V. Nystagmus intensity and direction in bow and lean test: an aid to diagnosis of lateral semicircular canal benign paroxysmal positional vertigo. Acta Otorhinolaryngol Ital 2016;36:520-6. https://doi.org/10.14639/0392-100X-795.

45 Argaet EC, Bradshaw AP, Welgampola MS. Benign positional vertigo, its diagnosis, treatment and mimics. Clin Neurophysiol Pract 2019;4:97-111. https://doi.org/10.1016/j.cnp.2019.03.001.

46 Casani AP, Cerchiai N, Navari E. Paroxysmal positional vertigo despite complete vestibular impairment: the role of instrumental assessment. Acta Otorhinolaryngol Ital 2018;38:563-8. https://doi. org/10.14639/0392-100X-1549.

47 Sakaida M, Takeuchi K, Ishinaga H, et al. Long-term outcome of benign paroxysmal positional vertigo. Neurology 2003;60:1532-4. https://doi.org/10.1212/01.wnl.0000061477.03862.4d.

48 Prokopakis EP, Chimona T, Tsagournisakis M, et al. Benign paroxysmal positional vertigo: 10-year experience in treating 592 patients with canalith repositioning procedure. Laryngoscope 2005;115:1667-71. https://doi.org/10.1097/01. mlg.0000175062.36144.b9.

49 Parnes LS, McClure JA. Free-floating endolymph particles: a new operative finding during posterior semicircular canal occlusion. Laryngoscope 1992;102:988-92. https://doi.org/10.1288/00005537199209000-00006.

50 Boleas-Aguirre M, Sánchez-Ferrándiz N, Artieda J, et al. Vestibular evoked myogenic potentials and benign paroxysmal positional vertigo. Acta Otorrinolaringol Esp 2007;58:173-7.

51 Yang WS, Kim SH, Lee JD, et al. Clinical significance of vestibular evoked myogenic potentials in benign paroxysmal positional vertigo. Otol Neurotol 2008;29:1162-6. https://doi.org/10.1097/ MAO.0b013e31818a0881.

52 Korres S, Gkoritsa E, Giannakakou-Razelou D, et al. Vestibular 
evoked myogenic potentials in patients with BPPV. Med Sci Monit 2011;17:CR42-47. https://doi.org/10.12659/msm.881328.

53 Lee JD, Park MK, Lee BD, et al. Abnormality of cervical vestibularevoked myogenic potentials and ocular vestibular-evoked myogenic potentials in patients with recurrent benign paroxysmal postitional vertigo. Acta Otolaryngol 2013;133:150-3. https://doi.org/10.3109/ 00016489.2012.723823.

54 Yetiser S, Ince D, Gul M. An analysis of vestibular evoked myogenic potentials in patients with benign paroxysmal positional vertigo. Ann Otol Rhinol Laryngol 2014;123:686-95. https://doi. org/10.1177/0003489414532778.

55 Longo G, Onofri M, Pellicciari T, et al. Benign paroxysmal positional vertigo: is vestibular evoked myogenic potential testing useful? Acta Otolaryngol 2012;132:39-43. https://doi.org/10.3109/000 16489.2011.619570.

$56 \mathrm{Xu} \mathrm{H}$, Liang FY, Chen L et al. Evaluation of the utricular and saccular function using oVEMPs and cVEMPs in BPPV patients. $\mathrm{J}$ Otolaryngol Head Neck Surg 2016;45:12. https://doi.org/10.1186/ s40463-016-0125-7.

57 Singh NK, Apeksha K. Efficacy of cervical and ocular vestibularevoked myogenic potentials in evaluation of benign paroxysmal positional vertigo of posterior semicircular canal. Eur Arch Otorhinolaryngol 2016;273:2523-32. https://doi.org/10.1007/s00405-015-3867-3.
58 Chang MY, Shin JH, Oh KH, et al. Clinical implication of cervical vestibular evoked myogenic potentials in benign paroxysmal positional vertigo. Clin Neurophysiol 2017;128:351-6. https://doi. org/10.1016/j.clinph.2016.12.004.

59 Hoseinabadi R, Pourbakht A, Yazdani N, et al. The effects of $a b$ normality of cVEMP and oVEMP on rehabilitation outcomes in patients with idiopathic benign paroxysmal positional vertigo. Eur Arch Otorhinolaryngol 2016;273:643-8. https://doi.org/10.1007/ s00405-015-3612-y.

60 Karataş A, Yüce T, Çebi IT, et al. Evaluation of cervical vestibularevoked myogenic potential findings in benign paroxysmal positional vertigo. J Int Adv Otol 2016;12:316-20. https://doi.org/10.5152/ iao.2016.2170.

61 Silva TR, de Resende LM, Santos MAR. Combined ocular and cervical vestibular evoked myogenic potential in individuals with vestibular hyporeflexia and in patients with Ménière's disease. Braz J Otorhinolaryngol 2017;83:330-40. https://doi.org/10.1016/j. bjorl.2016.04.017.

62 Chen L, Xu H, Wang WQ, et al. Evaluation of the otolith function using c/oVEMPs in patients with Ménière's disease. J Otolaryngol Head Neck Surg 2016;45:39. https://doi.org/10.1186/s40463-016$0152-4$.

Received: February 11, 2018 - Accepted: February 23, 2019

How to cite this article: Scarpa A, Gioacchini FM, Cassandro E, et al. Clinical application of cVEMPs and oVEMPs in patients affected by Ménière's disease, vestibular neuritis and benign paroxysmal positional vertigo: a systematic review. Acta Otorhinolaryngol Ital 2019;39:298-307. https://doi.org/10.14639/0392-100X-2104

Address for correspondence: Federico Maria Gioacchini, Otolaryngology Department, Polytechnic University of Marche, Ospedali Riuniti of Ancona, via Conca 71, 60020 Torrette (AN), Italy. E-mail: giox83@ hotmail.com 